\title{
An A-E assessment of post-ICU COVID-19 recovery
}

\author{
Matthew Cadd ${ }^{*}$ and Maya Nunn
}

\begin{abstract}
The COVID-19 global pandemic has placed unprecedented strain on healthcare and critical care services around the world. Whilst most resources have focused on the acute phase of the disease, there is likely to be an untold burden of patients chronically affected.

A wide range of sequelae contribute to post intensive care syndrome (PICS); from our current knowledge of COVID19, a few of these have the potential to be more prevalent following critical care admission. Follow-up assessment, diagnosis and treatment in an increasingly virtual setting will provide challenges but also opportunities to develop these services. Here, we propose an A to E approach to consider the potential long-term effects of COVID-19 following critical care admission.

Anxiety and other mental health diagnoses

Breathlessness

Central nervous system impairment

Dietary insufficiency and malnutrition

Embolic events

Developing strategies to mitigate these during admission and providing follow-up, assessment and treatment of persistent multiple organ dysfunction will be essential to improve morbidity, mortality and patient quality of life.

Keywords: COVID-19, Recovery, Critical care, Mental health, Dyspnoea, Anosmia, Nutrition, Embolism
\end{abstract}

\section{Background}

COVID-19 has caused a global surge in critical care demand not previously seen in history. COVID-19 has the potential to have a protracted course, a significant number of patients show symptoms lasting more than 8 weeks $[1,2]$. As more COVID-19 critical care survivors begin their recovery, there may be some unique features of post COVID-19 intensive care syndrome that will require ongoing assessment and follow-up. Here, we aim to provide some wider considerations of these based on the limited data from current post COVID-19 research and also extrapolated from longer term data from other critical care populations and notably previous respiratory virus pandemics.

\footnotetext{
* Correspondence: matthew.cadd@nhs.net

Intensive Care Unit, Royal Sussex County Hospital, Brighton BN2 5BE, UK
}

\begin{abstract}
Main text
Anxiety, depression and post-traumatic stress disorder (PTSD) are frequently seen following critical care admission; in pre-pandemic studies, $35-45 \%$ of patients met diagnostic criteria for anxiety 12 months following discharge and $18 \%$ meeting diagnostic criteria for all three diagnoses [3, 4]. Risk factors for developing mental health disorders following critical care admission include longer periods of mechanical ventilation and delirium [5]. Given COVID-19 patients are requiring longer periods of mechanical ventilation and sedation, combined with dexamethasone being used for treatment, these patients are predisposed to higher rates of delirium and subsequent mental health disorders [6, 7]. The effect of social isolation on patients, before, during and after critical care admission should be taken into account; a small
\end{abstract}

(C) The Author(s). 2021 Open Access This article is licensed under a Creative Commons Attribution 4.0 International License, which permits use, sharing, adaptation, distribution and reproduction in any medium or format, as long as you give appropriate credit to the original author(s) and the source, provide a link to the Creative Commons licence, and indicate if changes were made. The images or other third party material in this article are included in the article's Creative Commons licence, unless indicated otherwise in a credit line to the material. If material is not included in the article's Creative Commons licence and your intended use is not permitted by statutory regulation or exceeds the permitted use, you will need to obtain permission directly from the copyright holder. To view a copy of this licence, visit http://creativecommons.org/licenses/by/4.0/. The Creative Commons Public Domain Dedication waiver (http://creativecommons.org/publicdomain/zero/1.0/) applies to the data made available in this article, unless otherwise stated in a credit line to the data. 
number of studies have shown that loneliness and resulting depression has increased during the pandemic $[8,9]$.

Additionally, there could be a direct neurological effect of the SARS-CoV-2 as was noted with SARS-CoV and MERS or indirect as part of the systemic sequalae of the disease [10]. Either way, there are reports of widespread neurological effects of COVID-19; a study from Wuhan found patients with more severe COVID-19 had higher rates of neurological outcomes (45\% compared to $36 \%$ in those with less severe disease) [11]. A biological cause for mental health problems following infection should not be overlooked.

Critical care diaries have been shown to reduce PTSD; these would not only provide a story of their admission as documented by staff but could be used to communicate messages from relatives unable to visit during admission [12].

Offering critical care follow-up to discuss specific concerns and screening for mental health disorders, in either a clinic or primary care setting, using a suitable questionnaire such as the GHQ-28, will be particularly important in post critical care COVID-19 patients [13-15].

Breathlessness, reduced exercise tolerance and impaired pulmonary function were common amongst patients following the previous SARS epidemic and have been shown to cause considerable morbidity following COVID-19 [16, 17]. Anaemia, respiratory muscle dysfunction, deconditioning, pulmonary embolism and anxiety can all contribute to the often-multifactorial nature of post critical care breathlessness [18]. Early planning for rehabilitation whilst patients are still in critical care is important to have the greatest impact on recovery [19].

Pulmonary rehabilitation (PR) aims to increase functional capacity, reduce symptoms and improve quality of life [18]. PR is multifaceted and requires patient education, psychosocial support, exercise prescription and medical optimisation.

Virtual PR has shown some early promise in COVID19 patients, including video classes, booklets and telephone appointments [20]. Remote assessment with a 6-min walk test using a mobile application combined with a home pulse oximetry could be used to help stratify patients who need further input and face-to-face assessment [21, 22].

Central nervous system impairment and particularly chemosensory disturbance has shown to be a common symptom of COVID-19. A recent meta-analysis has shown olfactory dysfunction and taste dysfunction to be present in $38.5 \%$ and $30.4 \%$ of COVID-19 patients, respectively [23]. As opposed to other viral causes of anosmia or hyposmia, it is thought that COVID-19 is neurotropic rather than causing nasal congestion $[24,25]$.

Although some studies report anosmia as being indicative of less severe disease and lower mortality, a significant number of critical care patients still report chemosensory disturbance [26]. Critical care acquired weakness and loss of muscle mass may be exacerbated by lack of enjoyment in eating and subsequent malnutrition due to absent taste and smell [27].

Although there is limited evidence in COVID-19 to date, olfactory training is a treatment that can be completed remotely and has shown to be effective for sensorineural olfactory loss [28-30].

Dietary intake is an important consideration for all critical care patients. COVID-19 has presented its own challenges for providing nutrition to patients in critical care including debate around if nasogastric tube insertion is aerosol generating and potential challenges of enteral feeding in proned patients [31,32].

To date there have been no studies looking specifically at the nutritional status of COVID-19 critical care patients. As previously discussed, COVID-19 patients have required a prolonged length of stay compared to other critical care patients. This combined with the hypercatabolic state it induces put this group at higher risk of malnutrition and subsequent complications [6,33]. Inadequate nutritional intake in critical care patients has shown to increase mortality and time to physical recovery [34].

Post extubation dysphagia, critical care acquired weakness, anosmia and ageusia are factors that will make it challenging for patients to meet their nutritional requirements. A nutritional plan, with regular assessment and progressive physical exercise should be the mainstay of recovery [35].

Embolic and thrombotic events have been more prevalent in the COVID-19 critical care population, $31 \%$ and $5 \%$ of patients have been shown to have venous and arterial thromboembolisms, respectively [36-39]. COVID-19 has been shown to cause profound hypercoagulability, complement activation and cytokine storm [40, 41], which can lead to widespread embolic events in the arterial and venous systems. Longer periods of immobility, staffing constraints and isolation restrictions may further increase clot risk [42].

Pulmonary embolism, cerebrovascular accident, myocardial infarction and limb ischaemia can cause significant morbidity and mortality both immediately and chronically. Early adequate therapeutic anticoagulation and recognition of the aforementioned diagnosis will help to reduce clot burden whilst not increasing bleeding incidence [43, 44].

Although no long-term data currently exists for embolic risk post COVID-19 (both in patients with confirmed VTE and those without), there should be risk stratification for further thrombosis and haemorrhagic risk and consideration of longer treatment or empirical anticoagulation [45]. 


\section{Conclusion}

COVID-19 has so far shown to be a multi-organ disease affecting all ages. Although PICS is well-recognised in critical care survivors, there is limited evidence of the chronic effects of COVID-19 in post critical care patients at present [46]. We believe PICS will be prevalent following COVID-19 but the symptoms and diagnoses discussed here may be unique to COVID-19 and should be considered following critical care discharge.

As public health restrictions continue to be dynamic, the medium for providing assessment should minimise face to face contact so as to maintain some consistency in service provision. A wide-ranging multidisciplinary team both in primary and secondary care will be required to address the aforementioned sequalae and additional ones not discussed here. Current guidelines suggest rehabilitation assessment and initiation of treatment should start whilst patients remain in critical care [47].

Treatment of these conditions are wide ranging from psychological to pharmacological. As more data emerges about specific complications in this patient group, treatment strategies and guidelines will be implemented and updated. More extensive guidelines have been produced elsewhere highlighting current best practice for on-going assessment and treatment of post-acute COVID-19 in the community setting [20].

Multi-centre longitudinal studies are currently underway to assess the long-term impact of COVID-19 and the needs of COVID-19 patients who have been hospitalised. Analysis of these large studies should guide best practice [48].

The unifying aim of assessing each of the aspects of post COVID-19 care is to adequately treat patients to reduce morbidity and mortality, improve quality of life and help enable patients to return to their previous baseline of physical and mental functionality.

\section{Abbreviations}

COVID-19: Coronavirus disease 2019; PICS: Post intensive care syndrome; PPE: Personal protective equipment; PTSD: Post-traumatic stress disorder; GHQ-28: General Health Questionnaire 28; SARS: Severe acute respiratory syndrome; PR: Pulmonary rehabilitation; VTE: Venous thromboembolism

\section{Acknowledgements}

Not applicable

\section{Authors' contributions}

MC and MN have both contributed to, read and approved the final manuscript.

\section{Funding}

Not applicable

\section{Availability of data and materials}

We have not collected or analysed any data.

\section{Declarations}

Ethics approval and consent to participate Not applicable
Consent for publication

We consent for the below manuscript to be published.

\section{Competing interests}

The authors declare that they have no competing interests.

Received: 17 December 2020 Accepted: 7 March 2021

Published online: 20 March 2021

\section{References}

1. Carfi A, Bernabei R, Landi F. Persistent symptoms in patients after acute COVID-19. Jama. 2020;324(6):603-5. https://doi.org/10.1001/jama.2020.12603.

2. COVID Symptom Study. How long does COVID-19 last? Kings College London, 2020. https://covid19.joinzoe.com/post/covid-long-term?fbclid=IwA R1RxlcmmdL-EFjh_al- (Accessed 12 Dec 2020).

3. Hatch R, Young D, Barber V, Griffiths J, Harrison DA, Watkinson P. Anxiety, Depression and Post Traumatic Stress Disorder after critical illness: a UKwide prospective cohort study. Crit Care. 2018;22(1):310. https://doi.org/1 0.1186/s13054-018-2223-6.

4. Nikayin S, Rabiee A, Hashem MD, Huang M, Bienvenu OJ, Turnbull AE, Needham DM. Anxiety symptoms in survivors of critical illness: a systematic review and meta-analysis. Gen Hosp Psychiatry. 2016;43:23-9. https://doi. org/10.1016/j.genhosppsych.2016.08.005.

5. Desai SV, Law TJ, Needham DM. Long-term complications of critical care. Crit Care Med. 2011;39(2):371-9. https://doi.org/10.1097/CCM.0b013e3181 fd66e5.

6. Grasselli G, Zangrillo A, Zanella A, Antonelli M, Cabrini L, Castelli A, et al. Baseline characteristics and outcomes of 1591 patients infected with SARSCoV-2 admitted to ICUs of the Lombardy Region, Italy. JAMA. 2020;323(16): 1574-81. https://doi.org/10.1001/jama.2020.5394.

7. RECOVERY Collaborative Group. Dexamethasone in hospitalized patients with Covid-19. N Engl J Med. 2021;384(8):693-704. https://doi.org/10.1056/ NEJMoa2021436.

8. Lee CM, Cadigan JM, Rhew IC. Increases in loneliness among young adults during the COVID-19 pandemic and association with increases in mental health problems. J Adolesc Health. 2020;67(5):714-7. https://doi.org/10.1016/ j.jadohealth.2020.08.009.

9. Lewis K. COVID-19: Preliminary data on the impact of social distancing on loneliness and mental health. J Psychiatr Pract. 2020;26(5):400-4. https://doi. org/10.1097/PRA.0000000000000488.

10. Li YC, Bai WZ, Hashikawa T. The neuroinvasive potential of SARS-CoV2 may play a role in the respiratory failure of COVID-19 patients. J Med Virol. 2020; 92(6):552-5. https://doi.org/10.1002/jmv.25728.

11. Mao L, Jin H, Wang M, Hu Y, Chen S, He Q, Chang J, Hong C, Zhou Y, Wang D, Miao X, Li Y, Hu B. Neurologic Manifestations of Hospitalized Patients With Coronavirus Disease 2019 in Wuhan, China. JAMA Neurol. 2020;77(6): 683-90. https://doi.org/10.1001/jamaneurol.2020.1127.

12. Jones C, Bäckman C, Capuzzo M, Egerod I, Flaatten H, Granja C, et al. Intensive care diaries reduce new onset post traumatic stress disorder following critical illness: a randomised, controlled trial. Crit Care. 2010;14(5): R168. https://doi.org/10.1186/cc9260.

13. Goldberg DP, Williams P. A user's guide to the General Health Questionnaire. London (UK): NFER; 1988

14. Lee AM, Wong JG, MCAlonan GM, Cheung V, Cheung C, Sham PC, Chu CM, Wong PC, Tsang KW, Chua SE. Stress and psychological distress among SARS survivors 1 year after the outbreak. Can J Psychiatry. 2007:52(4):233-40. https://doi.org/10.1177/070674370705200405.

15. Moreno C, Wykes T, Galderisi S, Nordentoft M, Crossley N, Jones N, et al. How mental health care should change as a consequence of the COVID-19 pandemic. Lancet Psychiatry. 2020;7(9):813-24. https://doi.org/10.1016/S221 5-0366(20)30307-2

16. Ngai JC, Ko FW, Ng SS, To KW, Tong M, Hui DS. The long-term impact of severe acute respiratory syndrome on pulmonary function, exercise capacity and health status. Respirology. 2010;15(3):543-50. https://doi.org/10.1111/ j.1440-1843.2010.01720.x.

17. Belli S, Balbi B, Prince I, et al. Low physical functioning and impaired performance of activities of daily life in COVID-19 patients who survived hospitalisation. Eur Respir J. 2020;56:2002096. https://doi.org/10.1183/13993 003.02096-2020

18. Barker-Davies RM, O'Sullivan O, Senaratne KP, Baker P, Cranley M, DharmDatta S, et al. The Stanford Hall consensus statement for post-COVID-19 
rehabilitation. Br J Sports Med. 2020;54(16):949-59. https://doi.org/10.1136/ bjsports-2020-102596.

19. National Institute for Health and Care Excellence (NICE). Rehabilitation after critical illness in adults. 2017, www.nice.org.uk/guidance/qs158 (Accessed: 12 Dec 2020)

20. Greenhalgh T, Knight M, Buxton M, Husain L. Management of post-acute covid-19 in primary care. BMJ. 2020;11:370.

21. Salvi D, Poffley E, Orchard E, Tarassenko L. The Mobile-Based 6-Minute Walk Test: Usability Study and Algorithm Development and Validation. JMIR mHealth uHealth. 2020;8(1):e13756. https://doi.org/10.2196/13756.

22. Hull JH, Lloyd JK, Cooper BG. Lung function testing in the COVID-19 endemic. The Lancet Respir Med. 2020;8(7):666-7. https://doi.org/10.1016/ S2213-2600(20)30246-0.

23. von Bartheld CS, Hagen MM, Butowt R. Prevalence of chemosensory dysfunction in COVID-19 Patients: a systematic review and meta-analysis reveals significant ethnic differences. ACS Chem Neurosci. 2020;11(19):294461. https://doi.org/10.1021/acschemneuro.0c00460.

24. Baig AM, Khaleeg A, Ali U, Syeda H. Evidence of the COVID-19 virus targeting the CNS: tissue distribution, host-virus interaction, and proposed neurotropic mechanisms. ACS Chem Neurosci. 2020;11(7):995-8. https://doi. org/10.1021/acschemneuro.0c00122.

25. Parma V, Ohla K, Veldhuizen MG, Niv MY, Kelly CE, Bakke AJ, Cooper KW, Bouysset C, Pirastu N, Dibattista M, Kaur R. More than smell-COVID-19 is associated with severe impairment of smell, taste, and chemesthesis. Chem Senses. 2020;45(7):609-22. https://doi.org/10.1093/chemse/bjaa041.

26. Sayın P, Altınay M, Cınar AS, Ozdemir HM. Taste and Smell Impairment in Critically III Patients With COVID-19: An Intensive Care Unit Study. Ear Nose Throat J. 2020. https://doi.org/10.1177/0145561320977464.

27. Latronico N, Herridge M, Hopkins RO, Angus D, Hart N, Hermans G, Iwashyna T, Arabi Y, Citerio G, Ely EW, Hall J. The ICM research agenda on intensive care unit-acquired weakness. Intensive Care Med. 2017:43(9):127081. https://doi.org/10.1007/s00134-017-4757-5.

28. Soler ZM, Patel ZM, Turner JH, Holbrook EH. A primer on viral-associated olfactory loss in the era of COVID-19. Int Forum Allergy Rhinol. 2020; (in press). Epub 10 Nov 2020. https://doi.org/10.1002/alr.22578.

29. Pekala K, Chandra RK, Turner JH. Efficacy of olfactory training in patients with olfactory loss: a systematic review and meta-analysis. Int Forum Allergy Rhinol. 2016;6(3):299-307. https://doi.org/10.1002/alr.21669.

30. Walker A, Pottinger G, Scott A, Hopkins C. Anosmia and loss of smell in the era of COVID-19. BMJ. 2020;21:370.

31. Sturrock BR, Fanning SJ, Khan M, Sajid MS. Should nasogastric tube insertion during the COVID-19 pandemic be considered as an aerosol-generating procedure? Br J Hosp Med. 2020;81(6):1-6. https://doi.org/10.12968/hmed.2 020.0307 .

32. Blaser AR, Starkopf J, Alhazzani W, Berger MM, Casaer MP, Deane AM, et al. Early enteral nutrition in critically ill patients: ESICM clinical practice guidelines. Intensive Care Med. 2017;43(3):380-98. https://doi.org/10.1007/ s00134-016-4665-0.

33. Thibault R, Seguin P, Tamion F, Pichard C, Singer P. Nutrition of the COVID19 patient in the intensive care unit (ICU): a practical guidance. Crit Care. 2020;24(1):1-8.

34. Wei $X$, Day AG, Ouellette-Kuntz H, Heyland DK. The association between nutritional adequacy and long-term outcomes in critically ill patients requiring prolonged mechanical ventilation: a multicenter cohort study. Crit Care Med. 2015;43(8):1569-79. https://doi.org/10.1097/CCM.0000000000001 000.

35. Barazzoni R, Bischoff SC, Breda J, Wickramasinghe K, Krznaric Z, Nitzan D, Pirlich $M$, Singer P. ESPEN expert statements and practical guidance for nutritional management of individuals with SARS-CoV-2 infection. Clinical Nutrition. 2020;39(6):1631-8. https://doi.org/10.1016/j.clnu.2020.03.022.

36. Klok FA, Kruip MJ, Van der Meer NJ, Arbous MS, Gommers DA, Kant KM, Kaptein FH, van Paassen J, Stals MA, Huisman MV, Endeman H. Confirmation of the high cumulative incidence of thrombotic complications in critically ill ICU patients with COVID-19: an updated analysis. Thromb Res. 2020;191: 148-50. https://doi.org/10.1016/j.thromres.2020.04.041.

37. Minet C, Potton L, Bonadona A, Hamidfar-Roy R, Somohano CA, Lugosi M, Cartier JC, Ferretti G, Schwebel C, Timsit JF. Venous thromboembolism in the ICU: main characteristics, diagnosis and thromboprophylaxis. Crit Care 2015;19(1):287. https://doi.org/10.1186/s13054-015-1003-9.

38. Cook D, Crowther M, Meade M, Rabbat C, Griffith L, Schiff D, Geerts W Guyatt G. Deep venous thrombosis in medical-surgical critically ill patients: prevalence, incidence, and risk factors. Read Online Crit Care Med Soc Crit Care Med. 2005;33(7):1565-71. https://doi.org/10.1097/01.CCM.0000171207. 95319.B2.

39. Malas MB, Naazie IN, Elsayed N, Mathlouthi A, Marmor R, Clary B. Thromboembolism risk of COVID-19 is high and associated with a higher risk of mortality: A systematic review and meta-analysis. EClinicalMedicine. 2020;29:100639.

40. Magro C, Mulvey JJ, Berlin D, Nuovo G, Salvatore S, Harp J, Baxter-Stoltzfus A, Laurence J. Complement associated microvascular injury and thrombosis in the pathogenesis of severe COVID-19 infection: a report of five cases. Transl Res. 2020;220:1-3. https://doi.org/10.1016/j.trsl.2020.04.007.

41. Tang N, Li D, Wang X, Sun Z. Abnormal coagulation parameters are associated with poor prognosis in patients with novel coronavirus pneumonia. J Thromb Haemost. 2020;18(4):844-7. https://doi.org/10.1111/ jth. 14768.

42. Mondal S, Quintili AL, Karamchandani K, Bose S. Thromboembolic disease in COVID-19 patients: A brief narrative review. J Intensive Care. 2020;8(1):1-0.

43. Thachil J, Tang N, Gando S, Falanga A, Cattaneo M, Levi M, Clark C, Iba T. ISTH interim guidance on recognition and management of coagulopathy in COVID-19. J Thromb Haemost. 2020;18(5):1023-6. https://doi.org/10.1111/ jth. 14810.

44. Pavoni V, Gianesello L, Pazzi M, Stera C, Meconi T, Frigieri FC. Venous thromboembolism and bleeding in critically ill COVID-19 patients treated with higher than standard low molecular weight heparin doses and aspirin: A call to action. Thromb Res. 2020;196:313-7. https://doi.org/10.1016/j. thromres.2020.09.013.

45. Bikdeli B, Madhavan MV, Jimenez D, Chuich T, Dreyfus I, Driggin E, Nigoghossian C, Ageno W, Madjid M, Guo Y, Tang LV, Hu Y, Giri J, Cushman M, Quéré I, Dimakakos EP, Gibson CM, Lippi G, Favaloro EJ, Fareed J, Caprini JA, Tafur AJ, Burton JR, Francese DP, Wang EY, Falanga A, McLintock C, Hunt BJ, Spyropoulos AC, Barnes GD, Eikelboom JW, Weinberg I, Schulman S, Carrier M, Piazza G, Beckman JA, Steg PG, Stone GW, Rosenkranz S, Goldhaber SZ, Parikh SA, Monreal M, Krumholz HM, Konstantinides SV, Weitz I, Lip GYH, Global COVID-19 Thrombosis Collaborative Group, Endorsed by the ISTH, NATF, ESVM, and the IUA, Supported by the ESC Working Group on Pulmonary Circulation and Right Ventricular Function. COVID-19 and Thrombotic or Thromboembolic Disease: Implications for Prevention, Antithrombotic Therapy, and Follow-Up. J Am Coll Cardiol. 2020;75(23): 2950-73. https://doi.org/10.1016/j.jacc.2020.04.031.

46. Rawal G, Yadav S, Kumar R. Post-intensive care syndrome: an overview. J Transl Intern Med. 2017:5(2):90-2. https://doi.org/10.1515/jtim-2016-0016.

47. Phillips M, Turner-Stokes L, Wade D, Walton K. Rehabilitation in the wake of Covid-19-a phoenix from the ashes. Br Soc Rehabil Med. 2020. https://www. bsrm.org.uk/downloads/covid-19bsrmissue1-published-27-4-2020.pdf. Accessed 10 Dec 2020.

48. The Post-hospitalisation COVID-19 study (PHOSP-COVID), https://www. phosp.org/ (Accessed: 1 July 21).

\section{Publisher's Note}

Springer Nature remains neutral with regard to jurisdictional claims in published maps and institutional affiliations.

Ready to submit your research? Choose BMC and benefit from:

- fast, convenient online submission

- thorough peer review by experienced researchers in your field

- rapid publication on acceptance

- support for research data, including large and complex data types

- gold Open Access which fosters wider collaboration and increased citations

- maximum visibility for your research: over $100 \mathrm{M}$ website views per year

At $\mathrm{BMC}$, research is always in progress.

Learn more biomedcentral.com/submissions 